\title{
Ultrastructural description of Myxobolus cuneus (Myxosporea) in the skeletal muscle and kidney of tropical farmed fish Piaractus mesopotamicus (Characiformes: Characidae)
}

\author{
Wilson Gómez Manrique ${ }^{1}$ Mayra Araguaia Pereira Figueiredo ${ }^{2}$. \\ Marco Antonio de Andrade Belo ${ }^{1,3}$ • Maurício Laterça Martins ${ }^{4} \cdot$ Carlos Azevedo $^{5}$
}

Received: 22 February 2016 / Accepted: 17 March 2016 /Published online: 28 March 2016

(C) Springer-Verlag Berlin Heidelberg 2016

\begin{abstract}
This study characterizes by transmission electron microscopy (TEM) and morphometric features the myxozoan Myxobolus cuneus (Myxosporea) in Piaractus mesopotamicus and reports the skeletal muscle and kidney as site of infection. The register was based in 21 young fish from intensive fish farming in Southeast Brazil and the spores were analyzed in fresh-mounted slides of the infected organs stained with Toluidine blue and processed as usual for TEM. It differs from Myxobolus cunhai from the fish host and different polar capsule size, and from Myxobolus serrasalmi on the pyriform spore shape and an oval macrospore, differently to that reported in this study. Morphometric characteristics and TEM study confirmed the present material as M. cuneus.
\end{abstract}

Keywords Freshwater fish $\cdot$ Pacu $\cdot$ Myxozoa $\cdot$ Transmission electron microscopy

Wilson Gómez Manrique wilsongomezmanrique@yahoo.es

1 Department of Veterinary Pathology, Camilo Castelo Branco University, Descalvado Campus. Av. Hilário da Silva Passos, Descalvado CEP: 13690-000, São Paulo, Brazil

2 Department of Parasitology, Institute for Biomedical Sciences, University of São Paulo, São Paulo 05508-000, Brazil

3 Department of Preventive Veterinary Medicine, São Paulo State University, Via de acesso Prof. Paulo Donato Castellane s/n, Jaboticabal 14884-900, São Paulo, Brazil

4 Aquatic Organisms Health Laboratory, Aquaculture Department, Federal University of Santa Catarina, Rod. Admar Gonzaga 1346, Florianópolis 88040-900, Santa Catarina, Brazil

5 Department of Cell Biology, Institute of Biomedical Sciences, University of Porto, Largo Prof. Abel Salazar 2, 4099-003 Porto, Portugal

\section{Introduction}

Piaractus mesopotamicus (Characidae: Myleinae) commonly known as "pacu" is a native omnivorous fish of great economic importance in Brazil (Manrique et al. 2015a). High stocking density and inadequate handling are responsible for increased stress that negatively affect the fish health causing more susceptibility to diseases including the myxozoan parasites. These parasites may develop intra and intercellular (histozoic) or located in the organs and body cavity (coelozoic) (Lom and Dyková 1992). They can be found in the gills, skin, liver, spleen, kidney, gallbladder, intestines, swim bladder, cartilage, and muscle, but some of them may be found in the subcutaneous tissue provoking deformations visible in naked eye (Brites-Neto and Thatcher 1994). In the skin, the plasmodia are easily visible (Baska 1986) and Myxobolus genus was also recorded in the internal organs (Adriano et al. 2006), blood (Maciel et al. 2011), brain (Baldwin et al. 2000), and kidney (Manrique et al. 2012).

Some species of the genus Myxobolus parasiting the skeletal muscle were described as Myxobolus sp. in $P$. mesopotamicus and did not present neither inflammation signs nor degree of myofibrillar degeneration (Manrique et al. 2015b). Other authors (Székely et al. 2009) described the infection of Myxobolus omari in the sutchi catfish Pangasianodon hypophthalmus and Myxobolus leptobarbi in the mad barb Leptobarbus hoevenii causing host cell damages with engulfed spores by melanomacrophages. Hypertrophy and vertebral fusion were also observed in Myxobolus buckey infection in the skeletal muscle of cyprinid fishes Leuciscus cephalus, Rutilus rutilus, and Abramis brama (Longshaw et al. 2003).

Molnár and Kovács-Gayer (Molnár and Kovács-Gayer 1985) and Baska (1986) have also reported Myxobolus cyprini 
and Myxobolus pseudodispar, spores in the skeletal muscle. Ogawa et al. (1992) observed high infections of Myxobolus artus in the muscle of common carp, Cyprinus carpio affecting the fish growth. Pernicious anemia of carp caused by $M$. cyprini and muscle infection in Stizostedion lucioperca caused by Myxobolus sandrae were considered the most important pathogenic species for freshwater fish (Shulman 1966; Azevedo et al. 2012).

The conventional diagnosis of myxozoan is based mainly on their microscopical observation or imprinting of tissues. On the other hand, it reduces the possibility of correct identification of developmental stages of spores (Manrique et al. 2013). Ultrastructural identification has been used to establish the similarities among the species (Matos et al. 1999; AbdelGhaffar et al. 2005) but comparatively few studies consider the histopathology to complement the myxozoan diagnosis and host consequences (Martins et al. 1997; Ali et al. 2002; Adriano et al. 2005, 2006, 2009; Campos et al. 2011).

The aim of this study was to characterize by transmission electron microscopy the morphology of the myxozoan Myxobolus cuneus in the skeletal muscle and kidney of a Neotropical freshwater fish P. mesopotamicus, in Brazil.

\section{Materials and methods}

Twenty-one young fish with $120.0 \pm 5.0 \mathrm{~g}$ mean weight and $18.4 \pm 3.2 \mathrm{~cm}$ standard length were captured during July 2014 from the intensive fish farming in Southeast Brazil, São Paulo State; the place of study is private and is not characterized as a reserve, and has been approved by the owner of the property. During this period, the water quality was kept as follows: dissolved oxygen $5.0 \pm 0.8 \mathrm{mg} / \mathrm{L}$, temperature $29.4 \pm 0.3{ }^{\circ} \mathrm{C}$, $\mathrm{pH} 7.6 \pm 0.8$, electrical conductivity $117.9 \pm 1.8 \mu \mathrm{S} / \mathrm{cm}$, measured with an YSI Model MPS 556 equipment. The studied fish species are not endangered and are species of commercial production.

Immediately after each collection, the fish were euthanized in a benzocaine solution 1:500 v/v and then necropsied. The procedures were carried out in accordance with the Guide for the Care and Use of Laboratory Animals and the experimental protocol was approved by the Committee of Ethics in the Use of Animals, CEUA - "Comissão de Ética no uso de Animais" (protocol n ${ }^{\circ}$ 020092/09) from the São Paulo State University.

The fish were dissected and the cysts were removed from the skeletal muscle and spores from kidney tissue for examination in a light microscope equipped with differential interference contrast microscopy (Olympus BX51) with image capture in a DP73 Olympus camera (software cell Sens v. $1.5)$ and a camera lucida.

For ultrastructural studies, fragments of infected skeletal muscle and kidney were fixed in $3 \%(v / v)$ glutaraldehyde in $0.2 \mathrm{M}$ sodium cacodylate buffer ( $\mathrm{pH} 7.2)$ for $20 \mathrm{~h}$ at $4{ }^{\circ} \mathrm{C}$, washed three times in the buffer for an hour at $4{ }^{\circ} \mathrm{C}$ and postfixed in $2 \%(w / v) \mathrm{OsO}_{4}$ buffered with $0.2 \mathrm{M}$ sodium cacodylate for $2 \mathrm{~h}$ at the same temperature. The fragments were dehydrated in an ascending ethanol and propylene oxide series and embedded in Epon. Fresh-mounted slides of the infected organs were stained with Toluidine blue (TB). Ultrathin sections $(60 \mathrm{~nm})$ were cut with diamond knife, contrasted with uranyl acetate and lead citrate and observed in a JEOL JEM-1010 TEM (JEOL Optical, Tokyo, Japan) operated at $70 \mathrm{kV}$.

\section{Results}

Description The spore's morphology were the same in both tissues. The morphometry of $M$. cuneus in the present study was compared with other species of Myxobolus identified in Brazilian fish (Table 1). Mature fresh spores $(n=126)$ had an oval body with a length $8.9 \pm 0.3 \mu \mathrm{m}$, spore width $5.7 \pm 0.3 \mu \mathrm{m}$, two equal polar capsules $4.3 \pm 0.3 \mu \mathrm{m}$ long and $1.9 \pm 0.1 \mu \mathrm{m}$ wide (Fig. 1). Schematic drawing of matures spores shows the arrangement of the structures and organelles (Fig. 2). The spores wall thin and smooth measured $65.0 \pm 0.3 \mathrm{~nm}$ thickness comprising two valves joint by a suture line (Figs. 3 and 4). Polar filaments were coiled in 7-8 turns perpendicularly to the axis of the capsule (Fig. 5). In the median region of the spore a binucleated sporoplasm provided by several electron-dense vesicles, sporoplasmosomes, and a single nucleus was observed, this latter measuring $346.0 \pm 0.3 \mathrm{~nm}$ in diameter with a dense chromatin with no evidence of nucleolus (Figs. 6 and 7). Espores in different maturations stages (Fig. 8).

Type host Teleost fish P. mesopotamicus (Holmberg, 1887) (Osteichthyes: Characidae).

Site of infection Plasmodia located in the striated skeletal muscle and spores in the posterior kidney.

Prevalence Fourteen of 21 fish (66.7\%) had spores in the striated skeletal muscle and 17 of 21 fish showed spores in the posterior kidney $(80.9 \%)$.

Type locality Center for the Research and Management of Continental Fishing Resources (Cepta, Ibama), Pirassununga, São Paulo State, Brazil.

New locality Fish farm in the region of Bauru, São Paulo State, Brazil $\left(22^{\circ} 7^{\prime} 18^{\prime \prime} \mathrm{S}, 47^{\circ} 27^{\prime} 13^{\prime \prime} \mathrm{W}\right)$.

Type material Slides with hematoxylin-eosin and ZiehlNeelsen stained spores deposited in the histopathological collection (number 35785) of Veterinary Pathology Department, São Paulo State University (UNESP), Jaboticabal, SP, Brazil. 
Table 1 Comparative measurements (mean values in $\mu \mathrm{m}$ ) of Myxobolus sp. spores and those found in the skeletal muscle and kidney ( $\mathrm{n}=126)$ of $P$. mesopotamicus

\begin{tabular}{llllllllll}
\hline Hosts & Site of infection & Species & SL & SW & ST & PCL & PCW & PFC & Authors \\
\hline C. heckelii & Gills & M. heckelii & 12.7 & 6.6 & 4.0 & 2.9 & 1.7 & $4.0-5.0$ & Azevedo et al. (2009) \\
Myleus rubripinnis & Gallbladder & M. myleus & 19.3 & 8.3 & 4.0 & 13.2 & 3.0 & $19-21$ & Azevedo et al. (2012) \\
Zungaro jahu & Skin & M. cordeiroi & 10.9 & 7.5 & 5.6 & 5.3 & 1.4 & $5.0-6.0$ & Adriano et al. (2009) \\
Pimelodus ornatus & Cardiac muscle & Myxobolus sp. & 8.0 & 5.8 & 3.4 & 3.6 & 1.2 & - & Matos et al. (2014) \\
P. mesopotamicus & Kidney & Myxobolus sp. & 8.9 & 5.5 & - & 4.4 & 2.4 & - & Manrique et al. (2015a, b) \\
Serrasalmus sp. & Spleen, kidney & M. serrasalmi & 9.7 & 4.7 & - & 4.3 & 1.6 & - & Walliker (1969) \\
Pygocentrus piraya & Intestine & M. cunhai & 10 & 5.0 & - & - & - & - & Penido (1927) \\
P. mesopotamicus & Kidney & M. cuneus & 8.9 & 5.5 & - & 4.4 & 2.4 & - & Present study \\
P. mesopotamicus & Skeletal muscle & M. cuneus & 8.9 & 5.6 & 8.3 & 4.5 & 2.4 & $7.0-8.0$ & Present study \\
\hline
\end{tabular}

$S L$ spore length, $S W$ spore width, $S T$ spore thickness, $P C L$ polar capsule length, $P C W$ polar capsule width, $P F C$ polar filament coils

Histopathology Plasmodia provoked dissociation of muscular fibers. No inflammatory reaction. Spores were found to be situated in the peritubular interstitial space of kidney causing reduction of tubule lumen and those located in the glomerulus caused reduced Bowman capsule and increased glomerular tuff.

\section{Discussion}

The TEM of the spores from the muscle and kidney of $P$. mesopotamicus showed morphology and ultrastructure that resembles the spores of $M$. cuneus from $P$. mesopotamicus (Manrique et al. 2012, 2013, 2015b) but no information on ultrastructural description of this species in kidney was found.

The present specimens resemble the morphology of $M$. serrasalmi (Walliker 1969), Myxobolus inaequus (Kent and Hoffman 1984), M. cunhai (Gioia and Cordeiro 1996), M. cunhai (Molnár and Békési 1992), M. maculatus (Casal et al. 2002), and M. cuneus (Adriano et al. 2006), but only

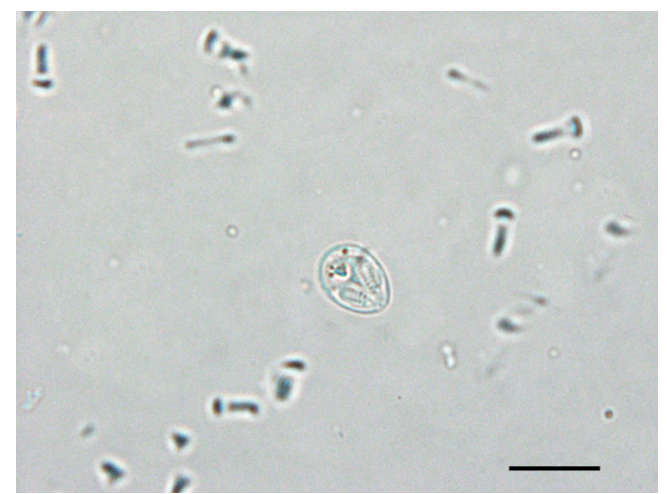

Fig. 1 Mature spores of M. cuneus light photomicrographs. Scale bar $=10 \mu \mathrm{m}$ spores of $M$. cunhai, M. serrasalmi, and M. cuneus were morphometricaly similar to the present material. However, M. cunhai was described in Pygocentris piraya and the spores showed different polar capsule size (Gioia and Cordeiro 1996).

On the other hand, the spores of $M$. serrasalmi were pyriform with an oval macrospore (Molnár and Békési 1992) differently to that reported in this study. Nevertheless, morphometric characteristics of $M$. cuneus from $P$. mesopotamicus (Adriano et al. 2006; Manrique et al. 2012) were too close suggesting that this material belongs to this species.

Spores of Myxobolus sp. were also registered in the hematopoietic organs such as M. serrasalmi in Serrasalmus sp. (Walliker 1969); central nerve system of rainbow trout Oncorhynchus mykiss, brown trout Salmo trutta (Baldwin et al. 2000), in the blood of tambaqui Colossoma macropomum (Adriano et al. 2006); in the connective tissue of the swim

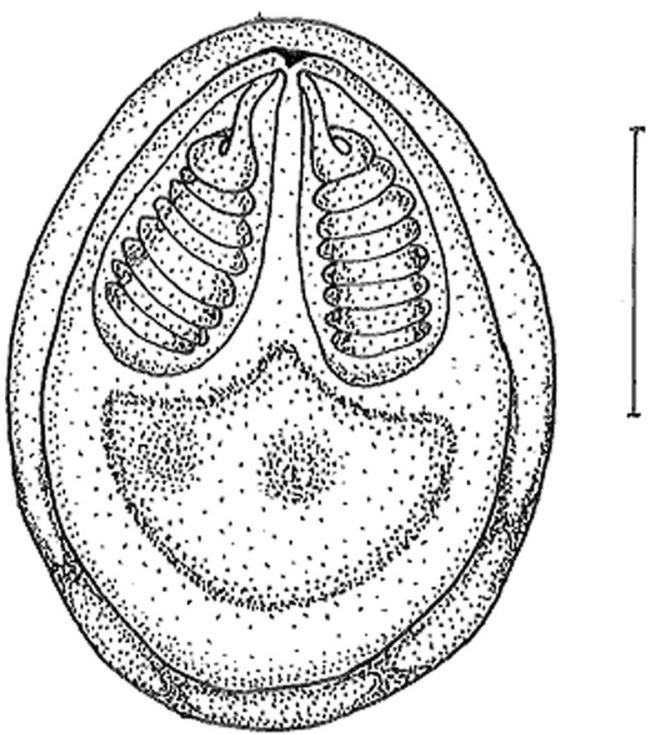

Fig. 2 Schematic drawing of mature spores of M. cuneus. Scale bar $=5 \mu \mathrm{m}$ 
Figs. 3-8 Transmission electron microscopy of $M$. cuneus parasite from the skeletal muscle and kidney of P. mesopotamicus. (3) Transversal section of the spore em maturation process showing the valves $(V)$, polar capsule $(P C)$, polar filaments (arrowhead), spore wall $(W)$, nucleus $(N)$ and sporoplasm in development $(i S)$. (4) Mature spore separated by a thin wall $(W)$, observe the polar filaments developed $(P F)$ in different electondense degrees (arrow end), sporoplasm ( $S p$ ), nucleus $(N)$, and the suture line of the valves (arrow). (5) Detail of polar capsule and wall $(W)$ and polar filaments (arrow). (6) Mature and immature spore. In mature spore note the polar capsule $(P C)$ wall spore $(W)$ polar filaments (arrow end) and suture line in valves (arrow). In immature note the nuclei $(N)$, sporoplasm $(S p)$. (7). Immature spore, note the nucleus $(N)$, polar filaments (arrow end), sporoplasm $(S p)$, spore wall $(W)$, and suture line (arrow). (8)

Mature and immature spores. Note polar capsules $(P C)$, nuclei $(N)$, sporoplasm $(S p)$, polar filaments (arrow), and spore wall. Scale bar $=500 \mathrm{~nm}$
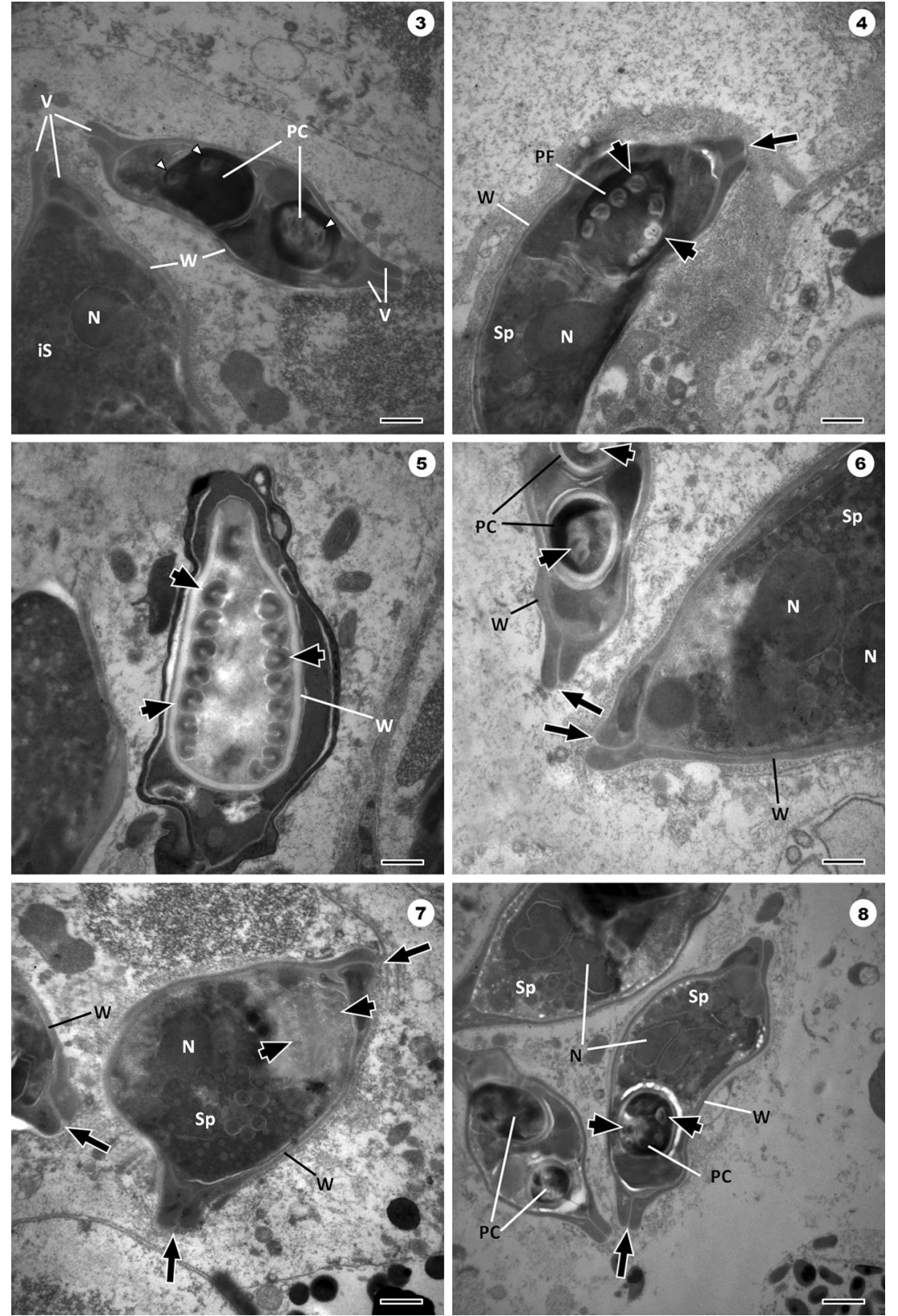

bladder, urinary bladder, gills, spleen, fin rays, liver, heart, and subcutaneous tissue of the head of P. mesopotamicus (Adriano et al. 2006), Myxobolus stomum in the oral cavity and lips of the blackspotted grunt Plectorhynicus gaterinus (Ali et al. 2003), and Myxobolus lubati in the wall of the intestine of haffara seabream Rhabdosargus haffara (Ali et al. 2007). Manrique et al. $(2015 \mathrm{a}, \mathrm{b})$ reported spores of Myxobolus sp. in the skeletal muscle of $P$. mesopotamicus in which shows the importance of such finding on this host.

Myxobolus sp. spores located in the posterior kidney were found by Manrique et al. (2012) and other species were described in the muscular skeletal tissue in teleost fishes such as $M$. fryeri in coho-salmon, Oncorhynchus kisutch (Ferguson et al. 2008), M. omari in P. hypophthalmus and M. leptobarbi in L. hoevenii (Székely et al. 2009), M. artus in C. carpio (Ogawa et al. 1992). Although these species provoke pathological alterations and decreased survival (Longshaw et al. 2003), they are not considered the most pathogenic parasites differing form $M$. cyprini in C. carpio that produce the pernicious anemia of carp and $M$. sandrae in the muscle of perch, S. lucioperca (Shulman 1966).

In conclusion, the morphological and ultrastructural study contributes to the identification of the species $M$. cuneus and complements its original description with a new site of infection herein registered in the type host P. mesopotamicus. 
Acknowledgments The authors thank Maria Teresa Picinoto Maglia and Jose Augusto Maulin (Technical of the Transmission Electron Microscopy Laboratory, USP-FMRP, Ribeirão Preto, Brazil) and the Nacional Council of Scientific and Technological Development (CNPq) for grant to M.L. Martins (CNPq 305869-2014-8).

\section{References}

Abdel-Ghaffar F, Abdel-Baki AS, El Garhy M (2005) Ultrastructural characteristics of the sporogenesis of genus Myxobolus infecting some Nile fishes in Egypt. Parasitol Res 95:167-171

Adriano EA, Arana S, Cordeiro NS (2005) An ultrastructural and histopathological study of Hennguya pellucida n. sp. (Myxosporea: Myxobolidae) infecting Piaractus mesopotamicus (Characidae) cultivated in Brazil. Parasite 12:221-227

Adriano EA, Arana S, Cordeiro NS (2006) Myxobolus cuneus n. sp. (myxosporea) infecting the connective tissue of Piaractus mesopotamicus (Pisces: Characidae) in Brazil: histopathology and ultrastructure. Parasite 13:137-142

Adriano EA, Arana S, Alves AL, Silva MRM, Ceccarelli PS et al (2009) Myxobolus cordeiroi n. sp., a parasite of Zungaro jahu (Siluriformes: Pimelodidae) from Brazilian Pantanal: morphology, phylogeny and histopathology. Vet Parasitol 162:221-229

Ali MA, Al-Rasheid KA, Sakran T, Abdel-Baki AA, Abdel-Ghaffar F (2002) Some species of the genus Myxobolus (Myxozoa: Myxosporea) infecting freshwater fish of the River Nile, Egypt, and the impact on their hosts. Parasitol Res 88(1):9-15

Ali MA, Abdel-Baki AS, Sakran T, Entzeroth R, Abdel-Ghaffar F (2003) Light and electron microscopic studies of Myxobolus stomum n. sp. (Myxosporea: Myxobolidae) infecting the blackspotted grunt Plectorhynicus gaterinus (Forsskal, 1775) in the Red Sea, Egypt. Parasitol Res 91(5):390-397

Ali MA, Abdel Baki AS, Sakran T, Entzeroth R, Abdel-Ghaffar F (2007) Myxobolus lubati n.sp. (Myxosporea: Myxobolidae), a new parasite of haffara seabream Rhabdosargus haffara (Forsskal, 1775), Red Sea, Egypt: a light and transmission electron microscopy. Parasitol Res 100(4):819-827

Azevedo C, Casal G, Matos P, Ferreira I, Matos E (2009) Light and electron microscopy of the spore of Myxobolus heckelii $\mathrm{n}$. sp. (Myxozoa), parasite from the Brazilian fish Centromochlus heckelii (Teleostei: Auchenipteridae). J Eukaryot Microbiol 56:589-593

Azevedo C, São Clemente SC, Casal G, Matos P, Alves Â et al (2012) Myxobolus myleus n. sp. infecting the bile of the Amazonian freshwater fish Myleus rubripinnis (Teleostei: Serrasalmidae): morphology and pathology. Syst Parasitol 82(3):241-247

Baldwin TJ, Vincent ER, Silflow RM, Stanek D (2000) Myxobolus cerebralis infection in rainbow trout (Oncorhynchus mykiss) and brown trout (Salmo trutta) exposed under natural stream conditions. J Vet Diagn Invest 12:312-321

Baska F (1986) Histological studies on the development of Myxobolus pseudodispar Gorbunova, 1936 in the roach (Rutilus rutilus). Acta Vet Hung 35:251-257

Brites-Neto J, Thatcher VE (1994) Diagnóstico, prevenção e tratamento das enfermidades de peixes neotropicais de água doce. Rev Bras Med Vet 16:111-127

Campos MC, Moraes ERJ, Moraes RF (2011) Histopathology of gills of Piaractus mesopotamicus (Holmberg, 1887) and Prochilodus lineatus (Valenciennes, 1836) infested by monogenean and myxosporea, caugth in Aquidauana River, State of Mato Grosso do Sul, Brazil. Rev Bras Parasitol Vet 20:67-70

Casal G, Matos E, Azevedo C (2002) Ultrastructural data on the spore of Myxobolus maculatus n. sp. (phylum Myxozoa), parasite from the
Amazonian Fish Metynnis maculatus (Teleostei). Dis Aquat Org 51: $107-111$

Ferguson JA, Atkinson SD, Whipps CM, Kent ML (2008) Molecular and morphological analysis of Myxobolus spp. of salmonid fish with the description of a new Myxobolus species. J Parasitol 94:1322-1334

Gioia I, Cordeiro NS (1996) Brazilian myxosporidian's check-list (Myxozoa). Acta Protozool 35:137-149

Kent ML, Hoffman GL (1984) Two new species of Myxozoa, Myxobolus inaequus sp. n. and Henneguya theca sp. n. from the brain of a South American knife fish, Eigemannia virescens (V.). Protozool 31:91-94

Lom J, Dyková I (1992) Protozoan parasites of fishes. Elsevier, Amsterdam

Longshaw M, Frear P, Feist SW (2003) Myxobolus buckei sp. nov. (Myxozoa), a new pathogenic parasite from the spinal column of three cyprinid fishes from the United Kingdom. Folia Parasitol 50: 251-262

Maciel PO, Affonso EG, Boijink CL, Tavares-Dias M, Inoue LA (2011) Myxobolus sp. (Myxozoa) in the circulating blood of Colossoma macropomum (Osteichthyes, Characidae). Rev Bras Parasitol Vet 20:82-84

Manrique WG, Claudiano GS, Figueiredo MAP, Petrillo TR, Moraes JRE et al (2012) Myxosporidiosis in intensively-reared Piaractus mesopotamicus: histopathological diagnosis by means of ZiehlNeelsen staining. Pesq Vet Bras 32:1133-1137

Manrique WG, Figueiredo MAP, Claudiano GS, Martins ML, Moraes FR (2013) Extraction technique and recovery of myxozoan parasites from the paraffin-embedded kidney of Piaractus mesopotamicus. Biotemas 26:265-268

Manrique WG, Claudiano GS, Castro MP, Petrillo TR, Figueiredo MAP et al (2015a) Expression of cellular components in granulomatous inflammatory response in Piaractus mesopotamicus Model. PLoS One 10(3): e0121625

Manrique WG, Figueiredo MAP, Belo MAA, Martins ML, Moraes FR (2015b) First report of Myxobolus sp. infection in the skeletal muscle of Neotropical freshwater fish Piaractus mesopotamicus. Parasitol Res 114:2041-2044

Martins ML, Souza VN, Moraes FR, Moraes JRE, Costa AJ et al (1997) Pathology and behavioral effects associated with Henneguya sp. (Myxozoa: Myxobolidae) infections of captive pacu Piaractus mesopotamicus in Brazil. J World Aquac Soc 28 215-218

Matos E, Azevedo C, Corral L, Casal G, Matos P (1999) Ultraestrutura de protozoários parasitos de peixes da região Amazônica. Acta Amaz 29:575-585

Matos E, Videira M, Velasco M, Sanches O, São Clemente SC et al (2014) Infection of the heart of Pimelodus ornatus (Teleostei, Pimelodidae), by Myxobolus sp. (Myxozoa, Myxobolidae). Braz J Vet Parasitol 23(4):543-546

Molnár K, Békési L (1992) Description of a new Myxobolus species, $M$ colossomatis $\mathrm{n}$ sp from the teleost Colossoma macropomum of the Amazon River basin. J Appl Ichthyol 9:57-63

Molnár K, Kovács-Gayer E (1985) The pathogenicity and development within the host fish of Myxobolus cyprini Doflein, 1898. Parasitology 90:549-555

Ogawa K, Delgahapytiya KP, Furuta T, Wakabayashi H (1992) Histological studies on the host response to Myxobolus artus Akhmerov, 1960 (Myxozoa: Myxobolidae) infection in the skeletal muscle of carp, Cyprinus carpio L. J Fish Biol 41: 363-371

Penido JCN (1927) Quelques nouvelles Myxosporidies parasites de poissons d'eau douce du Brésil. CR Soc Brésil Biol 97:850-852

Shulman SS (1966) "Myxosporidian Fauna of the USSR." Acad Sci USSR Zool Inst Sci Publ. Moscow-Leningrad, USSR. (in Russian). 98111515700 
Székely C, Shaharom-Harrison YF, Cech G, Mohamed K, Molnár K (2009) Myxozoan pathogens of Malaysian fishes cultured in ponds and net-cages. Dis Aquat Org 8:49-57
Walliker D (1969) Myxosporidea of some Brazilian freshwater fishes. J Parasitol 55:942-948 